\title{
Walnut cultivars with perspectives for ecological culture in Romania
}

\author{
M. Botu ${ }^{1,2 *}$, S. Giura ${ }^{2}$, A. Scutelnicu ${ }^{2}$, G. Achim ${ }^{1,2}$, S. Cosmulescu ${ }^{1}$ and I. Botu ${ }^{1}$ \\ 1Department of Horticulture and Food Science, Faculty of Horticulture, \\ University of Craiova, Romania \\ 2 Fruit Growing Research - Extension Station, Valcea, \\ University of Craiova, Romania \\ *Corresponding author email: btmihai2@yahoo.com
}

ABSTRACT

The objectives of the present study were to analyze the behavior of 11 Romanian walnut cultivars and one French cultivar ('Franquette') in North East of Oltenia, under conventional and during conversion to organic nut production. During conventional growing, the highest mean yields were recorded for 'Jupânești' $(2.88$ t/ha), 'Valcor' (2.77 t/ha), 'Verisval' (2.58 t/ha), 'Unival' $(2.55 \mathrm{t} / \mathrm{ha})$ and in the case of organic production the highest yields were observed for 'Jupânești' (3.5 $t / h a)$, 'Valcor' (2.95 t/ha), 'Unival' (2.67 t/ha), 'Verisval' (2.62 t/ha), 'Valrex' ( $2.56 \mathrm{t} / \mathrm{ha})$ and 'Redval' ( $2.54 \mathrm{t} / \mathrm{ha})$. Nuts of these cultivars were subject to measurements regarding fruit size index, index of roundness, nut weight, kernel weight and kernel ratio. The nuts of each cultivar were divided according to class sizes for the international markets. Cultivars with more than $80 \%$ of nuts larger than $32 \mathrm{~mm}$ were: 'Valcris', 'Sibișel 44', 'Valcor', 'Germisara' and 'Franquette'. The walnut cultivars were evaluated depending on the attack of walnut blight (Xanthomonas arboricola pv. juglandis) and anthracnosis (Gnomonia leptostyla) on leaves and fruits. Walnut blight and anthracnosis attacks were observed on 'Sibisel 44', 'Germisara', 'Velnita' and 'Franquette', while the least affected proved to be: 'Valcor', 'Valcris', 'Unival', 'Jupânești' and 'Verisval'. As consequence, the following walnut cultivars have perspectives to be used for the ecological culture in Romania: 'Valcor', 'Jupânești', 'Valrex', 'Verisval', 'Unival', 'Redval', 'Velnița', 'Timval', 'Germisara', 'Valcris' and 'Franquette'.

Keywords: organic culture, Juglans regia, cultivar testing, crop, nut trees

\section{INTRODUCTION}

Walnut (Juglans regia L.), known also as Carpathian, Persian, or English walnut is a crop grown in over 60 countries in both hemispheres of the globe.

According to the FAO Stat Database (2021), Romania ranks $8^{\text {th }}(49,580 \mathrm{t})$ in the world in 2019 and $1^{\text {st }}$ in the E.U. (before France) in walnut production. This production comes mostly from semi-spontaneous walnuts on their roots, and only a small part comes from newly organized orchards (1,620 ha in 2019). Most walnuts, which are scattered in different areas, do not benefit from fertilizers and phytosanitary treatments, but they lack the official ecological certification and at the same time, they produce nuts of great variability and with diminished commercial value. 
Besides the general trend of establishing new and modern walnut orchards in most walnutgrowing countries there is an increasing interest for organic orchards and production Globally, organic walnut orchards occupied in 2019 an area of 50.540 ha, out of the 29.247 ha are fully converted and the rest under conversion. 37.000 ha of organic walnuts were counted in 2019 in China, 3728 ha in the U.S.A., 3262 ha in the Republic of Moldova, 1057 ha in Ukraine; 959 ha in Spain in 2018; 5499 ha in Turkey, 3625 ha in Italy, 682 ha in Serbia in 2017 (FIBL, 2021).

Organic agriculture comprised in Romania in 2019 an area of 395.228 ha, which represents $2.0 \%$ of the total area of farmland. Fruit crops occupy only 7.641 ha, respectively a share of $5.8 \%$ of the total organic agriculture at the national level. Out of 7641 ha of fruit orchards, 4144 ha are in a complete ecological system and the rest are under conversion. Nut crops are grown on 1273 ha, which is fully converted, while 2768 are under conversion (FIBL, 2021).

The cultivars recommended for organic farming in temperate continental climate countries are rustic genotypes, resistant to low winter temperatures, tolerant to main diseases and adapted to a climate quite rich in rainfall. Most of these cultivars come from selection activities carried out in local walnut populations.

The ecological principles (climate, orchard location, soil, and biocenosis), genetic and geographical origin of cultivars and rootstocks, and technological conditions are responsible for increasing productivity, fruit quality, and economic efficiency of the crop (Burke et al., 1976; Grimo, 1979; Botu, 1998; Botu et al., 2001; Aleta et al., 2014; Botu and Achim, 2014).

In the last 15 years, different walnut cultivars with terminal and lateral bearing were introduced in Romania, without any prior testing. That was the result of increased interest for planting new walnut orchards with the help of E.U. funds, lack of sufficient planting material, and aggressive advertising carried out by the plant material importers. In the areas with colder climates from Romania some of the introduced cultivars, in particular with lateral bearing, proved less adapted, temperatures below $-22^{\circ}$ to $-24^{\circ} \mathrm{C}$ during winter caused the death of young trees or affected their growth and yielding capacity. DeBuse, (2009); Aslamarz et al., (2010), Charrier et al., (2013), Gandev, (2013), Aleta et al., (2014), Botu et al., (2017 and 2018), confirmed the susceptibility of lateral bearing walnut cultivars to low temperatures and recommended that such cultivars be grown under suitable climatic conditions.

Research conducted at SCDP Valcea over the last 30 years has highlighted the value of walnut cultivars and the possibility of growing some of them organically (Botu et al., 2001; Botu and Tudor, 2005, Botu et al., 2010; Achim et al., 2018).

\section{MATERIALS AND METHODS}

The research has been carried out at Fruit Growing Research and Extension Station (SCDP) Vâlcea, belonging to the University of Craiova.

The walnut trial, without irrigation, is located in Bujoreni, in the North East of Oltenia Region, on an alluvial soil with $\mathrm{pH}=6.8$. The area has a Cfb Köppen - Geiger type (Rubel and Kottek, 2010) of climate, an average annual temperature of $10.2^{\circ} \mathrm{C}$ and $715 \mathrm{~mm}$ rainfall.

The study includes 12 walnut cultivars, all with terminal bearing. Eleven of them have been obtained in Romania: 'Jupânești' (from ICDP Pitesti - Maracineni); 'Germisara' and 'Sibișel 44' (from SCDP Geoagiu); 'Velnița' (from SCDP Iasi); 'Redval', 'Timval', 'Unival', 'Valcris', 'Valcor', 'Valrex' and 'Verisval' (obtained at SCDP Valcea) and one French cultivar ('Franquette'). Planting distances were 9 by $8 \mathrm{~m}$ (139 trees/ha) and each cultivar was represented by 5 trees. All cultivars were grafted on Juglans regia L. seedling rootstocks. Measurements and observations were carried out on the trees regarding growth, fruiting 
capacity, fruit quality, adaptability to environmental conditions, and natural resistance to diseases like walnut blight, caused by Xanthomonas arboricola pv. juglandis (Pierce) Vauterin, Hoste, Kersters \& Swings, and walnut anthracnosis, caused by Gnomonia leptostyla (DC.) Traverso, syn. Ophiognomonia leptostyla (Fr.) Sogonov.

Statistical analysis was performed using the Microsoft ${ }^{\circledR}$ Excel $^{\circledR}$ (2016) software for the analysis of variance (ANOVA) and DSAASTAT ver. 1.514 (2015) for the Tukey Multiple Range Test at a significance level of $\mathrm{p}<0.05$. DSAASTAT is an Excel VBA Macro developed by Onofri (2007). The data on conventional and organic yields were presented as mean \pm standard deviation (SD).

\section{RESULTS AND DISCUSSIONS}

The present study refers to the behavior of 11 Romanian walnut cultivars and the French cultivar 'Franquette' (Table 1), all of them with terminal bearing. 'Franquette' was used in the past as one of the main cultivars in different countries, due to its quality nuts and kernels. In the last decades 'Franquette' was used in the new orchards as a pollinating cultivar for lateral bearing ones.

Table 1. Nut yields of walnut cultivar grown conventionally* (18-year mean) and organic** (2-years mean)

\begin{tabular}{|c|c|c|c|c|c|c|}
\hline No. & Cultivar & $\begin{array}{l}\text { Country } \\
\text { of origin }\end{array}$ & $\begin{array}{l}\text { Type of } \\
\text { bearing }\end{array}$ & $\begin{array}{c}\text { Conventional yields - } \\
\text { mean of } 18 \text { years* } \\
\text { (t/ha) }\end{array}$ & $\begin{array}{c}\text { Organic yields for } \\
2019-2020 \\
\text { period }^{* *}(\mathrm{t} / \mathrm{ha})\end{array}$ & $\begin{array}{c}\text { Compared to } \\
\text { the } 18 \text {-year } \\
\text { mean }(\%)\end{array}$ \\
\hline 1 & 'Sibișel 44' & Romania & terminal & $1.97 \pm 0.30 \mathrm{~g}$ & $2.05 \pm 0.25^{b}$ & +4.06 \\
\hline 2 & 'Valcor' & Romania & terminal & $2.77 \pm 0.14^{\mathrm{a}}$ & $2.05 \pm 0.26^{b}$ & +6.50 \\
\hline 3 & 'Verisval' & Romania & terminal & $2.58 \pm 0.29^{b}$ & $2.52 \pm 0.27 \mathrm{ab}$ & +1.55 \\
\hline 4 & ‘Valrex’ & Romania & terminal & $2.25 \pm 0.13$ ef & $2.56 \pm 0.32 \mathrm{ab}$ & +13.80 \\
\hline 5 & 'Jupânești' & Romania & terminal & $2.88 \pm 0.10^{\mathrm{a}}$ & $3.05 \pm 0.24^{\mathrm{a}}$ & +5.90 \\
\hline 6 & 'Valcris' & Romania & terminal & $2.25 \pm 0.20$ ef & $2.24 \pm 0.25 \mathrm{ab}$ & -0.40 \\
\hline 7 & 'Germisara' & Romania & terminal & $2.22 \pm 0.26^{\mathrm{f}}$ & $2.18 \pm 0.24 \mathrm{ab}$ & -1.80 \\
\hline 8 & 'Velnița' & Romania & terminal & $2.41 \pm 0.28$ cde & $2.49 \pm 0.28 \mathrm{ab}$ & +3.30 \\
\hline 9 & 'Unival' & Romania & terminal & $2.55 \pm 0.22 \mathrm{bc}$ & $2.67 \pm 0.40 \mathrm{ab}$ & +4.70 \\
\hline 10 & 'Timval' & Romania & terminal & $2.32 \pm 0.18 \mathrm{def}$ & $2.4 \pm 0.24 \mathrm{ab}$ & +3.40 \\
\hline 11 & 'Redval' & Romania & terminal & $2.42 \pm 0.22 \mathrm{bcd}$ & $2.54 \pm 0.27^{\mathrm{ab}}$ & +5.00 \\
\hline 12 & 'Franquette' & France & terminal & $2.51 \pm 0.20 \mathrm{bc}$ & $2.53 \pm 0.17 \mathrm{ab}$ & +0.80 \\
\hline \multicolumn{4}{|c|}{ Mean $\pm S D$} & $2.43 \pm 0.07$ & $2.54 \pm 0.11$ & +4.53 \\
\hline
\end{tabular}

Means followed by the same letter are not significantly different (Tukey multiple range test. $p<0.05$ ).

The results obtained count 18 years of production of these cultivars, followed by two years on organic production, in the same trial, under conversion. From this point of view, during conventional growing, the highest mean yields were recorded for 'Jupânești' (2.88 t/ha), 'Valcor' (2.77 t/ha), 'Verisval' (2.58 t/ha), 'Unival' (2.55 t/ha), etc. The lowest mean yield was observed for 'Sibișel 44' (1.97 t/ha). Mean yields of 'Valcor' (2.77 t/ha) and 'Verisval' were statistically different ( $p>0.05$ ) from those of 'Verisval' (2.58 t/ha), 'Unival' ( $2.55 \mathrm{t} / \mathrm{ha})$, etc., but not different from each other. Yields obtained were largely affected in some years by low temperatures during blooming. Although during the study time the absolute minimum temperature was $-22.7^{\circ} \mathrm{C}$ (February 9th, 2012), the terminal bearing cultivars were not affected. Since the fall of 2018, the cultivars were studied under conversion to organic (ecological or biological) conditions, during 2019 and 2020. The cultivars maintained their yielding capacity in 2019 and 2020 on a relatively natural fertile soil, confirming the adaptability to the environmental conditions, including temperatures of $-2^{\circ} \mathrm{C}$ 
to $-3^{\circ} \mathrm{C}$ during April and drought during summer. Yields recorded were good for 'Jupânești' (3.5 t/ha), 'Valcor' (2.95 t/ha), 'Unival' (2.67 t/ha), 'Verisval' (2.62 t/ha), 'Valrex' (2.56 t/ha) and 'Redval' (2.54 t/ha). Statistically, differences ( $p>0.05)$ were observed between 'Jupânești', 'Valcor' and 'Sibișel 44', but no differences between the other cultivars tested.

The mean yields during 2019 and 2020 were 0.8-1.38 t/ha higher than the yield under conventional conditions (18 years mean), although low temperatures during flowering time negatively influenced walnut yields in 2019 and 2020.

Romanian walnut cultivars have biometric characteristics similar to other cultivars grown in different countries. Size index expressed as a mean of length, width, and height of walnuts varied during conventional conditions between $34.0 \mathrm{~mm}$ ('Jupânești') and $42.5 \mathrm{~mm}$ ('Sibișel 44 ') (Table 2). From the size point of view, large fruits, similar to 'Franquette' (35.6 mm) are found for all the other Romanian cultivars, except for ('Jupânești'). Differences are very small (0.94-2.0\%) between nuts of the same cultivar from the conventional system and those from the organic system. In the case of an average weight of fruits, the general mean was $13.83 \mathrm{~g}$ for the conventional system and $13.21 \mathrm{~g}$ for the organic one. Largest weight of walnuts was observed for the following cultivars: 'Valcris' (15.9 g, respectively $15.51 \mathrm{~g})$, 'Sibișel 44' (15.7 g, and $15.56 \mathrm{~g}$ ), 'Germisara' (14.6 g, and $15.11 \mathrm{~g}$ ), 'Unival' (14.5 g, respectively $13.31 \mathrm{~g}$ ), 'Valrex' (14.3 g, and $13.38 \mathrm{~g}$ ), 'Timval' (14.3 g, and $13.11 \mathrm{~g}$ ). On average, nut weight decreased by $4.52 \%$ in the case of the organic system. Medium sized fruits were obtained for 'Jupânești', 'Verisval' and 'Franquette'. Kernel weight of the cultivars varied from medium-small ('Jupânești' and 'Franquette') to medium ('Verisval' and 'Velnița') and large ('Valcris', 'Sibișel 44', 'Germisara', 'Redval', etc.). 'Redval' is the first Romanian cultivar with so called "red kernel", actually the tegument of the kernel is red. During the conventional orchard management, kernel ratio varied from $46.8 \%$ ('Franquette') to $53.9 \%$ ('Verisval'), while in the case of organic approach oscillated from $47.0 \%$ ('Sibișel 44 ') to $51.4 \%$ ('Timval'). Kernel ratio decreased on average by $1,8 \%$ for the organic systems (Table 2).

Table 2. Characteristics of walnuts cultivars under conventional* and organic** conditions

\begin{tabular}{|c|c|c|c|c|c|c|c|c|c|}
\hline \multirow[t]{2}{*}{ No. } & \multirow[t]{2}{*}{ Cultivar } & \multicolumn{2}{|c|}{$\begin{array}{l}\text { Mean fruit size index } \\
\text { (mm) }\end{array}$} & \multicolumn{2}{|c|}{$\begin{array}{c}\text { Mean nut weight } \\
(\mathrm{g})\end{array}$} & \multicolumn{2}{|c|}{$\begin{array}{l}\text { Mean kernel } \\
\text { weight }(\mathrm{g})\end{array}$} & \multicolumn{2}{|c|}{$\begin{array}{c}\text { Mean kernel ratio } \\
(\%)\end{array}$} \\
\hline & & $\begin{array}{c}18 \\
\text { years* }\end{array}$ & $\begin{array}{l}2019- \\
2020^{* *}\end{array}$ & $\begin{array}{c}18 \\
\text { years* }\end{array}$ & $\begin{array}{l}2019- \\
2020^{* *}\end{array}$ & $\begin{array}{c}18 \\
\text { years* }\end{array}$ & $\begin{array}{l}2019- \\
2020^{* *}\end{array}$ & $\begin{array}{c}18 \\
\text { years* }\end{array}$ & $\begin{array}{l}2019- \\
2020^{* *}\end{array}$ \\
\hline 1 & 'Sibișel 44' & 42.5 & 41.37 & 15.7 & 15.56 & 7.6 & 7.3 & 48.4 & 47.0 \\
\hline 2 & 'Valcor' & 36.9 & 37.05 & 13.3 & 13.24 & 7.1 & 6.78 & 53.3 & 51.2 \\
\hline 3 & 'Verisval' & 37.2 & 36.37 & 12.6 & 11.76 & 6.8 & 5.89 & 53.9 & 50.1 \\
\hline 4 & 'Valcris' & 37.6 & 37.07 & 15.9 & 15.51 & 7.9 & 7.54 & 49.7 & 48.6 \\
\hline 5 & 'Valrex' & 35.6 & 37.78 & 14.3 & 13.38 & 7.3 & 6.64 & 51.3 & 49.6 \\
\hline 6 & 'Timval' & 37.0 & 35.95 & 14.3 & 13.11 & 7.35 & 6.73 & 51.4 & 51.4 \\
\hline 7 & 'Unival' & 36.4 & 37.28 & 14.5 & 13.31 & 7.4 & 6.67 & 51.0 & 50.1 \\
\hline 8 & 'Jupânești' & 34.0 & 34.59 & 11.2 & 10.63 & 5.9 & 5.34 & 52.6 & 50.3 \\
\hline 9 & 'Germisara' & 42.4 & 39.36 & 14.6 & 15.11 & 7.3 & 7.37 & 50.0 & 48.8 \\
\hline 10 & 'Redval' & 35.7 & 35.31 & 13.5 & 13.48 & 6.8 & 6.82 & 50.4 & 50.6 \\
\hline 11 & 'Velnița' & 37.5 & 34.74 & 13.5 & 12.44 & 6.2 & 6.31 & 49.7 & 50.7 \\
\hline 12 & 'Franquette' & 35.6 & 33.93 & 12.6 & 11.00 & 5.9 & 5.39 & 46.8 & 49.0 \\
\hline & Mean & 37.28 & 36.93 & 13.83 & 13.21 & 6.96 & 6.57 & 50.7 & 49.8 \\
\hline Dif & erences (\%) & 100 & 98.52 & 100 & 95.48 & 100 & 94.4 & 100 & 98.2 \\
\hline
\end{tabular}

Walnut fruits from the cultivars analyzed showed coefficients of variability $(s \%)$ between $18.5 \%$ ('Velnița') and 22,7\% ('Jupânești'). The mean value of $s \%$ for all the 12 cultivars reached $19.53 \%$. As consequence, fruit variability falls into classes: below $20 \%$ (8 cultivars) 
and between $20-30 \%$ (4 cultivars). In total, the variability of fruits is more or less medium (Table 3).

Table 3. Coefficients of variability and size classes for the nuts of the studied cultivars

\begin{tabular}{|c|c|c|c|c|c|c|c|c|}
\hline \multirow[t]{2}{*}{ No. } & \multirow[t]{2}{*}{ Cultivar } & \multirow{2}{*}{$\begin{array}{l}\text { Coefficient of } \\
\text { variability for } \\
\text { nut size }(s \%)\end{array}$} & \multirow{2}{*}{$\begin{array}{c}\text { Large } \\
\text { diameter of } \\
\text { nuts }(\mathrm{mm})\end{array}$} & \multicolumn{4}{|c|}{$\begin{array}{l}\text { Size classes according to the equatorial } \\
\text { diameter of nuts }(\%)\end{array}$} & \multirow{2}{*}{$\begin{array}{c}\text { Index } \\
\text { of } \\
\text { roundness } \\
\text { (IR) }\end{array}$} \\
\hline & & & & $\begin{array}{l}>32 \\
\mathrm{~mm}\end{array}$ & $\begin{array}{c}30-32 \\
\mathrm{~mm}\end{array}$ & $\begin{array}{c}>28-30 \\
\mathrm{~mm}\end{array}$ & $\begin{array}{l}<28 \\
\mathrm{~mm}\end{array}$ & \\
\hline 1 & 'Sibișel 44' & 20.1 & 38.2 & 84.2 & 15.2 & 0.6 & 0 & 0.69 \\
\hline 2 & 'Valcor' & 17.5 & 36.6 & 82.0 & 16.1 & 1.9 & 0 & 0.86 \\
\hline 3 & 'Verisval' & 19.2 & 34.8 & 79.1 & 18.2 & 2.7 & 0 & 0.83 \\
\hline 4 & 'Valcris' & 18.9 & 38.8 & 84.5 & 14.8 & 0.7 & 0 & 0.85 \\
\hline 5 & 'Valrex' & 19.1 & 34.1 & 76.6 & 16.2 & 7.2 & 0 & 0.74 \\
\hline 6 & 'Timval' & 18.5 & 35.6 & 75.4 & 18.4 & 6.2 & 0 & 0.85 \\
\hline 7 & 'Unival' & 19.6 & 35.7 & 77.2 & 19.6 & 3.2 & 0 & 0.86 \\
\hline 8 & 'Jupânești' & 22.7 & 30.2 & 59.8 & 33.7 & 4.7 & 1.8 & 0.69 \\
\hline 9 & 'Germisara' & 21.4 & 40.4 & 81.7 & 17.7 & 0.6 & 0 & 0.78 \\
\hline 10 & 'Redval' & 18.7 & 34.8 & 75.6 & 18.4 & 6.0 & 0 & 0.77 \\
\hline 11 & 'Velnița' & 18.5 & 35.8 & 76.4 & 19.5 & 4.1 & 0 & 0.81 \\
\hline \multirow[t]{2}{*}{12} & 'Franquette' & 20.2 & 34.2 & 81.7 & 16.8 & 1.5 & 0 & 0.79 \\
\hline & Mean & 19.53 & 35.77 & 77.85 & 18.72 & 3.28 & 0.15 & 0.79 \\
\hline
\end{tabular}

Nuts were measured to determine the large diameter, which is an important indicator for grouping into size classes. All the 12 walnut cultivars fall into the extra $(>32 \mathrm{~mm})$ and $1^{\text {st }}$ class $(30-32 \mathrm{~mm}$ ) groups. Walnuts with diameters over $30 \mathrm{~mm}$ are more valuable on the international walnut trade. Cultivars with more than $80 \%$ of nuts $>32 \mathrm{~mm}$ are: 'Valcris', 'Sibișel 44', 'Valcor', 'Germisara' and 'Franquette' (Figure 1).

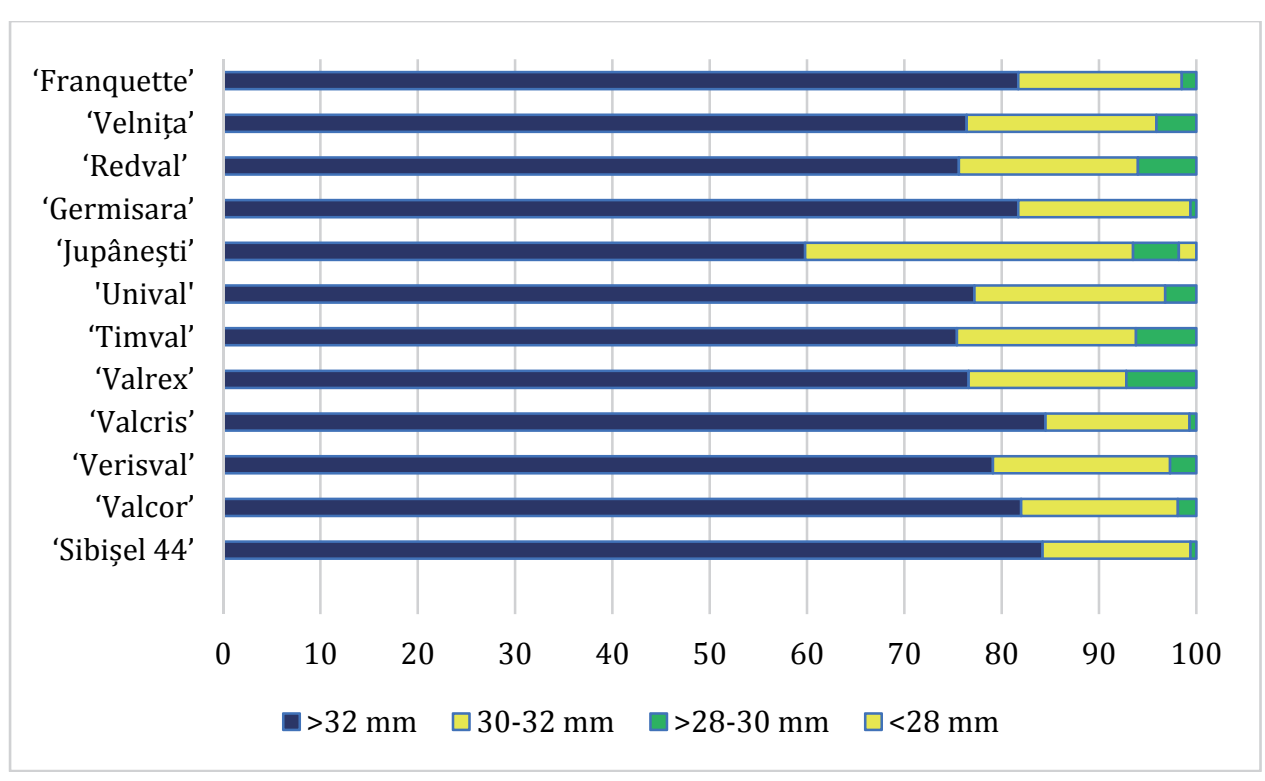

Figure 1. Diagram of nut sizes depending on the cultivar (\%)

In order to determine the shape of nuts, the index of roundness (IR) was calculated for the walnut cultivars as $I R=(D+d) / 2 h$, where $D$ is the length or the large diameter, $d$ is the width and $h$ the height of the nut. The roundness index varied between 0.69 ('Jupânesti' and 'Sibișel 44') to 0.86 ('Valcor' and 'Unival'). When the index of roundness is closer to 1.0, the more round is the nut (Botu et al., 2019). 
During the study, under the conversion to the organic system, the behavior of the walnut cultivars on main diseases like walnut blight (Xanthomonas arboricola pv. juglandis or Xaj) and anthracnosis (Gnomonia leptostyla) was analyzed. During the study, treatments with pesticides were accepted into organic agriculture (fungicides: Bouille bordelaise WDG and Funguran OH50WP; Microfort bactericide and insecticides: Laser 240 SC, Deffort and Ovipron Top). Disease incidence (DI) or frequency of attack (\%), disease severity (DS) or intensity of the attack (\%) and degree of attack (DA) were calculated.

Studies previously carried out by Botu M. et al., (2019) and Giura et al., (2020) on the behavior of walnut cultivars to the main diseases showed that the native cultivars are less affected than those with lateral bearing ones.

However, during the conversion to organic system, in the last three seasons, the attack of Xaj (Table 4) is different and oscillates on leaves from lower levels on 'Valcor' (DI $=5.90 \%$, DS = $4.16 \%, \mathrm{DA}=0.26$ ), to higher levels on 'Velnița' (DI $=12.55 \%$, DS $=7.53 \%$, DA $=1.06 \%$ ) and on fruit from lower levels for 'Unival' (DI $=8.0 \%$, DS $=6.27 \%$, DA $=0.56 \%$ ) to higher levels on 'Germisara' (DI $=15.36 \%$, DS $=11.37 \%$, DA $=2.40 \%$ ).

Table 4. Behavior of walnut cultivars to the attack of Xanthomonas campestris pv. juglandis (Xaj) on fruits and leaves in September (average of 3 years)

\begin{tabular}{|c|l|c|c|c|c|c|c|}
\hline No. & \multicolumn{1}{|c|}{ Cultivar } & \multicolumn{3}{|c|}{ Attack on leaves } & \multicolumn{3}{c|}{ Attack on fruits } \\
\cline { 3 - 8 } & & $\begin{array}{c}\text { Disease } \\
\text { incidence } \\
(\%)\end{array}$ & $\begin{array}{c}\text { Disease } \\
\text { severity } \\
(\%)\end{array}$ & $\begin{array}{c}\text { Degree } \\
\text { of attack } \\
(\%)\end{array}$ & $\begin{array}{c}\text { Disease } \\
\text { incidence } \\
(\%)\end{array}$ & $\begin{array}{c}\text { Disease } \\
\text { severity } \\
(\%)\end{array}$ & $\begin{array}{c}\text { Degree } \\
\text { of attack } \\
(\%)\end{array}$ \\
\hline 1 & 'Sibișel 44' & 11.03 & 7.63 & 0.93 & 12.89 & 16.67 & 1.58 \\
\hline 2 & 'Valcor' & 5.90 & 4.16 & 0.26 & 9.50 & 6.75 & 0.78 \\
\hline 3 & 'Verisval' & 7.41 & 4.21 & 0.68 & 8.21 & 5.85 & 0.53 \\
\hline 4 & 'Valcris' & 8.47 & 4.64 & 0.37 & 8.10 & 5.42 & 0.48 \\
\hline 5 & 'Valrex' & 7.57 & 4.82 & 0.38 & 7.49 & 5.69 & 0.46 \\
\hline 6 & 'Timval' & 7.25 & 4.72 & 0.34 & 8.30 & 6.31 & 0.59 \\
\hline 7 & 'Unival' & 6.56 & 4.82 & 0.55 & 8.00 & 6.27 & 0.56 \\
\hline 8 & 'Jupânești' & 10.92 & 6.74 & 0.84 & 14.25 & 11.20 & 2.12 \\
\hline 9 & 'Germisara' & 12.17 & 9.83 & 1.45 & 15.36 & 11.37 & 2.46 \\
\hline 10 & 'Redval' & 8.71 & 5.72 & 0.41 & 8.12 & 6.11 & 0.52 \\
\hline 11 & 'Velnița' & 12.55 & 7.53 & 1.06 & 11.87 & 8.85 & 1.18 \\
\hline 12 & 'Franquette' & 10.09 & 7.73 & 0.94 & 15.70 & 9.26 & 1.65 \\
\hline Mean & & 9.05 & 6.04 & 0.68 & 10.65 & 8.31 & 1.03 \\
\hline
\end{tabular}

Table 5. Behavior of walnut cultivars to the attack of Gnomonia leptostyla on leaves and fruits in September (average 3 years)

\begin{tabular}{|c|l|c|c|c|c|c|c|}
\hline \multirow{2}{*}{ No. } & Cultivar & \multicolumn{3}{|c|}{ Attack on leaves } & \multicolumn{3}{c|}{ Attack on fruits } \\
\cline { 3 - 8 } & & $\begin{array}{c}\text { Disease } \\
\text { incidence } \\
(\%)\end{array}$ & $\begin{array}{c}\text { Disease } \\
\text { severity } \\
(\%)\end{array}$ & $\begin{array}{c}\text { Degree } \\
\text { of attack } \\
(\%)\end{array}$ & $\begin{array}{c}\text { Disease } \\
\text { incidence } \\
(\%)\end{array}$ & $\begin{array}{c}\text { Disease } \\
\text { severity } \\
(\%)\end{array}$ & $\begin{array}{c}\text { Degree } \\
\text { of attack } \\
(\%)\end{array}$ \\
\hline 1 & 'Sibișel 44' & 16.06 & 8.79 & 1.41 & 9.16 & 7.09 & 0.65 \\
\hline 2 & 'Valcor' & 6.69 & 3.77 & 0.25 & 4.73 & 4.51 & 0.21 \\
\hline 3 & 'Verisval' & 6.24 & 3.85 & 0.24 & 4.3 & 3.81 & 0.16 \\
\hline 4 & 'Valcris' & 6.63 & 3.10 & 0.21 & 4.03 & 2.42 & 0.10 \\
\hline 5 & 'Valrex' & 6.10 & 3.33 & 0.20 & 4.83 & 3.53 & 0.17 \\
\hline 6 & 'Timval' & 6.08 & 3.24 & 0.20 & 4.75 & 4.50 & 0.21 \\
\hline 7 & 'Unival' & 6.45 & 3.07 & 0.20 & 3.75 & 2.45 & 0.09 \\
\hline 8 & 'Jupânești' & 11.87 & 6.53 & 0.78 & 7.09 & 4.42 & 0.31 \\
\hline 9 & 'Germisara' & 13.56 & 7.97 & 1.08 & 8.23 & 3.09 & 0.25 \\
\hline 10 & 'Redval' & 6.14 & 3.72 & 0.23 & 5.02 & 3.54 & 0.18 \\
\hline 11 & 'Velnița' & 11.25 & 8.04 & 0.90 & 6.31 & 5.29 & 0.33 \\
\hline 12 & 'Franquette' & 11.98 & 8.45 & 1.01 & 8.54 & 5.14 & 0.44 \\
\hline
\end{tabular}


In case of anthracnosis attack on leaves, the DI varied between $6.08 \%$ ('Timval') to $16.06 \%$ ('Sibișel 44') and DS between 3.07\% ('Unival') to 8.79\% ('Sibișel 44'). DA ranged between $0.20 \%$ ('Timval') and $1.44 \%$ ('Sibișel 44'). On fruits, the attack levels were low in case of 'Valcris' (DI $=4.03 \%$, DS $=2.42 \%$, DA $=0.11 \%$ ) and higher for 'Sibișel precoce' (DI $=9.16 \%$, DS $=7.09 \%, \mathrm{AA}=0.71 \%)$.

Walnut blight and anthracnosis attacks were more obvious on 'Sibișel 44', 'Germisara', 'Velnița' and 'Franquette', while the least affected were: 'Valcor', 'Valcris', 'Unival', 'Jupânești' and 'Verisval'.

The tolerant or less susceptible walnut cultivars to these diseases can be used successfully in organic orchards, as they have other qualities as it turned out from this study.

\section{CONCLUSIONS}

The results obtained in the 18 years of conventional cultivation and 2 years of organic cultivation under the conversion phase show that the Romanian walnut cultivars are better adapted to existing ecological conditions, have good productivity, are less affected by walnut blight and anthracnosis, and produce quality fruits and kernels that meet international trade requirements.

Taking into account the ecological principles of walnut cultivation and trends in increasing the production of healthy organic food, in accord with Regulation (EU) 2018/848 of the European Parliament and of the Council of 30 May 2018 on organic production and labeling of organic products, the following walnut cultivars are of perspective for the ecological culture in Romania: 'Valcor', 'Jupânești', 'Valrex', 'Verisval', 'Unival', 'Redval', 'Velnița', 'Timval', 'Germisara', 'Valcris' and 'Franquette'.

Organic farming can be improved with the help of new organic inputs and cultivars to be planted in the coming years in different suitable growing areas from Romania.

\section{ACKNOWLEDGEMENTS}

This work was supported by a grant of the Romanian Ministry of Research and Innovation, PCCDI-UEFISCDI, project number PN-III-P1-1.2-PCCDI-2017-0662, 12PCCDI/2018, within PNCDI III.

\section{REFERENCES}

1. Achim, Gh., Baciu, A., Botu, I., Botu, M., Cosmulescu, S., Glăman, Gh., and Godeanu, I. (2018). Walnut culture. Ed. Alma, Craiova.

2. Aleta, N., Vilanova, A., Tomas, E., and Guardia, M. (2014). Fruit resistance in seven commercial walnut cultivars. Acta Hort., 1050; 389-393.

3. Aslamarz, AA., Vahdati, K., Raheni, M., and Hassani, D. (2010). Cold - hardiness evolution of Persian walnut by terminal analysis and freezing technique. Acta Hort, 861; 269-272.

4. Botu, I., Botu, M. and Achim, G. (2001). Cultura nucului în exploataţii nucicole moderne. Editura Phoenix, Brașov.

5. Botu, M. (1998). Nut crops situation in Romania. FAO Nucis Newsletter 7; 23-24.

6. Botu, M., and Achim, Gh., (2014). Following Walnut Footprints in Romania; 327-335. In: Avanzato, D., McGranahan, G.H., Vahdati, K., Botu, M., Iannamico, L., Van Assche, J. Eds (2014). Following Walnut Footprints (Juglans regia L.) Cultivation and Culture, Folklore and History, Traditions and Uses. International Society for Horticultural Science (ISHS) and the International Nut and Dried Fruit Council (INC). Scripta Horticulturae No. 17. 
7. Botu, M., Alabedallat, Y.F.J., Bucura, F., Geană, E.I., and Vladu, M. (2019). The productive capacity and quality of several walnut cultivars (Juglans regia L.) Grown in North Oltenia, Romania. Notulae Botanicae Horti Agrobotanici Cluj-Napoca, 47(3); 574-579.

8. Botu, M., Botu, I., Achim, G., Stancu, A., and Alabedallat, Y.F.J. (2017). Evaluation of differentiation between Romanian walnut cultivars and those with lateral bearing from warmer areas. Annals of the Academy of Romanian Scientists Series on Agriculture, Silviculture and Veterinary Medicine Sciences. Volume 6, Number 2; 5-14.

9. Botu M., and Tudor, M. (2005). Comportarea unor soiuri de nuc în procesele de creștere și fructificare în zona subcarpatică a Olteniei. Ses. Șt. Referate ICDP Pitești - ASAS București.

10. Botu, M., Tudor, M., Botu, I., Cosmulescu, S., and Papachatzis, A. (2010). Evaluation of Walnut Cultivars in the Conditions of the Oltenia's Hill Area Regarding Functioning Potential. Analele Univ. din Craiova., Vol. XV (XLXI). Ed. Universitaria - Craiova; 94-103

11. Burke, M.J., Gusta, L.V., Quamme, H.A., Weiser, C.J. and Li, P.H. (1976). Freezing and injury in plants. Annual Review of Plant Physiology, 27: 507-528.

12. Charrier G., Poirier M., Bonhomme M., Lacointe A., and Améglio T. 2013. Frost Hardiness in Walnut Trees (Uuglans regia L.): How to link physiology and modelling? Tree Physiol; 33 (11): 1229-1241. DOI:10.1093/treephys/tpt090.

13. DeBuse, C. (2009). Managing walnuts for cold temperatures. Farmer Progress, USA. https://www.farmprogress.com/tree-nuts/managing-walnuts-cold-temperatures

14. Gandev, S. (2013). Winter hardiness of reproductive organs of the walnut cultivar. Bulgarian Journal of Agricultural Science, 19 (No 5), 1068-1070

15. Giura S, Botu M., Vulpe M, Vîjan L.E., Mitrea R. (2019). Evolution of the polyphenols, flavonoids, and tannins content in walnut leaves and green walnut husk during growing season. Notulae Botanicae Horti Agrobotanici Cluj-Napoca, 47(4), 1264-1271.

16. Grimo, E. (1979). Carpathian (Persian) walnuts. In: Jaynes RA (Ed). Nut tree culture in North America. Northern Nut Growers Association, Hamden, Connecticut, pp 74-83.

17. Onofri, A. (2007). Routine statistical analyses of field experiments by using an Excel extension. Proceeding's 6th National Conference Italian Biometric Society: "La statistica nelle scienze della vita e dell'ambiente", Pisa, (2007): 93-96.

18. Rubel, F., and Kottek, M. (2010). Observed and projected climate shifts 1901-2100 depicted by world maps of the Köppen-Geiger climate classification. Meteorol. Z., 19, 135-141. DOI 10.1127/0941-2948/2010/0430

19. DSAASTAT ver. 1.514 (2015) www.casaonofri.it/repository/DSAASTAT.xls

20. FAO Stat Database Web Page (2021). https://www.fao.org/faostat/en

21. FIBL Statistics Web Page (2021). https://statistics.fibl.org/ 